\title{
Comparative analysis of imaging examinations of the thoracic cage in neonates. Defining indications for cat scanning
}

\author{
Wojciech Sraga ${ }^{1}$, Jan Głowacki ${ }^{1,2}$, Ewa Kluczewska ${ }^{1}$, Jolanta Myga-Porosiło ${ }^{1}$, Tomasz Legaszewski $^{1}$, \\ Łukasz Czarnecki ${ }^{1}$, Katarzyna Król' ${ }^{1}$, Łukasz Kozioł ${ }^{1}$
}

${ }^{1}$ Katedra i Zakład Radiologii Lekarskiej i Radiodiagnostyki, Śląski Uniwersytet Medyczny w Katowicach, Zabrze

2Pracownia Diagnostyki Obrazowej, Śląskie Centrum Chorób Serca, Zabrze

Kardiochirurgia i Torakochirurgia Polska 2013; 10 (3): 295-298

\begin{abstract}
An X-ray of the thoracic cage is a fundamental examination in children with disorders of various origin. Despite the constantly decreasing role of classic radiology in imaging diagnostics, the X-ray photograph still remains the only method available in practice for imaging lung pathologies in neonates. The aim of the work is to define the indications for performing CAT scanning of the thoracic cage in children in the neonatal period on the basis of our own material. We analysed a group of neonates referred for thoracic cage CAT scanning. Out of 10 people examined, 8 were boys, and 2 were girls. Respiratory disorders or the presence of auscultatory phenomena were an indication for making an X-ray in neonates in whom a CAT scan of the thoracic cage was done. All neonates from the examined group had an X-ray only as a result of above-mentioned indications. On the basis of a classic X-ray photograph, it was not possible to differentiate the flaccidity of the diaphragm with diaphragmatic hernia; the suspicion of presence of patent emphysema ventricle also needed to be confirmed. In one neonate, $\mathrm{X}$-ray gave the image of an enlarged cone of the heart, and in the subsequent one, the image of persistent atelectasis of the right lower lobe. On the basis of the centre's experience, we may draw the conclusions that the basic indication for performing CAT scan examination in neonates is the suspicion of anatomical irregularity mentioned in the paper.
\end{abstract}

Key words: neonates, chest X-ray, CAT scanning.

\section{Introduction}

An X-ray of the thoracic cage is a fundamental examination in children with disorders of various origin. It is one of the first examinations carried out in neonates admitted to intensive care units. Additionally, it is frequently carried out by clinicians in cases of clinical state deterioration which is linked to the respiratory system.

\section{Streszczenie}

Podstawowym badaniem służącym do diagnozowania dzieci z różnego typu zaburzeniami oddychania jest zdjęcie radiologiczne klatki piersiowej. Mimo wciąż malejącej roli, jaką odgrywa radiologia klasyczna w diagnostyce obrazowej, zdjęcie RTG jest zasadniczo nadal jedyną dostępną metodą obrazowania patologii płucnych u noworodków. Natomiast w sytuacjach, gdy klasyczna metoda wydaje się niewystarczająca, należy rozważyć wykonanie tomografii komputerowej. W artykule opisano wybór grupy noworodków, u której wykonanie TK było wskazane. Przy wyborze należało uwzględnić wiele czynników. Najistotniejszym kryterium był stan ogólny noworodka oraz korzyść płynąca z badania, która musi przewyższać czynniki ryzyka i konsekwencje pochłonięcia dużej dawki promieniowania jonizującego. Celem pracy było określenie wskazań do wykonania tomografii komputerowej klatki piersiowej u dzieci w okresie noworodkowym na podstawie materiału pochodzącego z ośrodka, w którym pracują autorzy artykułu. Na podstawie przeprowadzonych badań wyciągnięto wnioski zawarte w pracy.

Słowa kluczowe: noworodki, zdjęcie RTG klatki piersiowej, tomografia komputerowa klatki piersiowej.

Despite the constantly decreasing role of classic radiology in imaging diagnostics, the X-ray photograph still remains the only method available in practice for imaging lung pathologies in neonates. However, in this area also, its role changes with the progress in neonatology; on one hand, it is limited to cases where monitoring respiratory and biochemical parameters is insufficient for the evalu-

Address for correspondence: dr n. med. Jan Głowacki, Pracownia Diagnostyki Obrazowej, Śląskie Centrum Chorób Serca, Skłodowskiej-Curie 9 Str., 41-800 Zabrze, phone/fax: +48 3237337 61, e-mail: j.glowacki@sccs.pl 
ation of the seriousness of the patient's condition, while on the other, the increased survival rate of preterm infants with a lowered survival threshold after childbirth of 23 weeks of gestational age [1] causes an increased requirement for roentgenographic examination.

Despite constant, quick progress in the field of imaging diagnostics, most modern methods are still not accessible for the examination of neonates, and especially preterm infants in a serious condition of respiratory and circulatory instability, requiring special conditions of constant homeostasis provision and respiratory support as well as constant monitoring of life parameters [2]. Moreover, due to the small size of the neonate's body, especially one with low birth weight, the resolving power for imaging body sections (e.g. high-resolution computed tomography [HRCT] of the lungs) is very often insufficient. Classic X-ray photographs, however, are directly available at neonate wards in the 'by-the-bed' system without the need to take a child out of the incubator. However, also in this method, the small size of the examined object (i.e. the thoracic cage of the preterm infant) creates great difficulty for examination, both for the roentgenology technician taking the photograph and the radiologist describing the radiogram, and the results of the examination are frequently ambiguous, so they are not satisfactory to a clinician.

While the classic radiogram is an insufficient imaging method, we should consider the use of CAT scanning. The application of this examination in a neonate faces significant technical difficulties. In conscious children, sedation is necessary as well as the synchronization of the respiratory phase with the examination stage. Additionally, the necessity of transporting a neonate in a serious state to the department of imaging diagnostics may be connected with complications.

Another issue is the dose of ionizing radiation, which is high in the case of CAT scanning, and the necessity to apply iodine contrast. When choosing the group of neonates in which the CAT scanning is to be done, one should take into consideration many factors. The general state of the neonate is essential as well as the benefit resulting from the examination, which should exceed the risk factors and consequences of receiving a large dose of ionizing radiation.

A classic X-ray photograph provides information on the pathological process in a specific localisation in lung tissue. However, it does not allow for making a precise diagnosis of the morphology of changes, and it only provides suspicions and constitutes the basis for further differential diagnosis. The limitation of the method's efficiency results mainly from a relatively wide mediastinum shadow in neonates, frequently with the participation of the large thymus, obscuring a significant part of the lung fields. However, due to the low diagnostic level accompanied by an increased radiation dose, lateral photographs are not carried out.

Taking into consideration the above impediments linked with classic radiological photographs, it is justified and useful to perform CAT scanning in neonates, which should be a decisive examination in many cases [3]. A med- ical team consisting of a radiologist, anaesthesiologist and paediatrician takes the decision about the necessity of carrying out CAT scanning, which should be performed exclusively in case of having more benefits than risks related to the examination.

\section{Aim of the work}

The aim of the work is to define the indications for performing CAT scanning of the thoracic cage in children in the neonatal period on the basis of our own material.

\section{Material and method}

Between January 2007 and July 2011, in the Clinic and Radiology Unit of ŚUM (Silesian Medical University) in Zabrze, 1483 neonates were examined. These were patients at the Clinic of Intensive Therapy and Pathology of Neonates at the Department of Paediatrics in Zabrze. In this period, 1365 neonates underwent an X-ray of the thoracic cage in order to evaluate the organs of the thoracic cage. In $10(0.73 \%)$ neonates of the analysed group, in whom an X-ray of the thoracic cage was made, it was decided to perform a CAT scan of the thoracic cage so as to widen the diagnostics, as the radiological image in classic examination was ambiguous, and the clinical state of the children alarming.

CAT scan examinations were performed at the laboratory of CAT scanning in the Clinic and Radiology Unit of ŚUM in Zabrze, using the apparatus GE Healthcare Light Speed 16. The following protocols of thoracic cage examinations were used for the examination: Thick Speer 1.25-2.50, Interval 1.25-2.50, $120 \mathrm{kV}, 115 \mathrm{~mA}$, Total exposure 2.0. CAT scanning was performed in the native stage and after administering the non-ionic contrast medium Visipaque 320.

The X-ray examination of the thoracic cage was made by means of the by-the-bed apparatus Siemens Polymobil Plus. We used the range of high voltage from 40 to $125 \mathrm{kV}$. The range of electric and time load was 0.5-200 mAs.

\section{Results}

We analysed a group of neonates referred for thoracic cage CAT scanning. Out of 10 people examined, 8 were boys, and 2 were girls.

Preterm infants constituted 50\% (5), of whom one neonate was born with extremely low birth weight < $1000 \mathrm{~g}$ (920 g, $26 \mathrm{Hbd}$, Apgar 6/6). One neonate was born with a birth weight < $2000 \mathrm{~g}$, four were born with birth weight between $2000 \mathrm{~g}$ and $3000 \mathrm{~g}$, and four with birth weight $>3000 \mathrm{~g}$.

In the examined group of children, five children were evaluated with 7 points, one with 8 points, three with 9 points, and one with 6 points on the Apgar scale.

Three neonates were born naturally, and 7 as a result of Caesarean section.

Respiratory disorders or the presence of auscultatory phenomena were an indication for making an X-ray in neonates in whom a CAT scan of the thoracic cage was done. 
They may correspond to innate disorders, functional disorders or inflammatory disorders. Besides these indications, there was a suspicion of developmental defect of lungs and/or heart, the evaluation of the position of the intubation tube and vascular catheter, pathological changes in the bone-joint system of the thoracic cage and the control of the applied treatment.

All neonates from the examined group had an X-ray only as a result of above-mentioned indications.

Before CAT scanning, the neonates had 64 X-ray photographs in total; a CAT scan was performed after $5 \mathrm{X}$-rays on average (30 photographs maximum, $1 \mathrm{X}$-ray minimum -1 neonate).

The CAT scan was performed most frequently between the $2^{\text {nd }}$ and $4^{\text {th }}$ week of life (9 examinations $-90 \%$ ), while one examination was made in the first week of life. CAT scanning was performed on average on the $15^{\text {th }}$ day of life, at the earliest on the fifth day of life, and at the latest on the twenty-sixth.

In 7 cases, the first $X$-ray photograph of the thoracic cage was made on the first day of life, in 3 cases on the second day of life, in neonates in whom CAT scanning was performed.

The CAT scanning of the examined group of neonates provided the following information: in 3 patients there was a necessity of differential diagnostics between interstitial emphysema and congenital cystic adenomatoid malformation (CCAM). In two others, the $\mathrm{X}$-ray gave a typical image for interstitial emphysema. In one neonate, the X-ray did not give an explicit answer to the origin of the shadow focus within the right lung. On the basis of a classic X-ray photograph, it was not possible to differentiate the flaccidity of the diaphragm from diaphragmatic hernia (in one neonate); the suspicion of presence of patent emphysema ventricle also needed to be confirmed (also in one neo- nate). In one neonate, $\mathrm{X}$-ray gave the image of an enlarged cone of the heart, and in one other, the image of persistent atelectasis of the right lower lobe (Table I).

CAT scanning gave an unequivocal result in 8 cases, and in 2 a doubtful one. The diagnoses made in CAT scanning included: 1 flaccidity of diaphragm, 1 lung sequestration/flaccidity of the diaphragm, 2 interstitial emphysemas, 1 subphrenic hematoma, 2 congenital cystic adenomatoid malformations (CCAM), 1 asymmetry of the thoracic cage, 1 inflammatory and atelectatic area, 1 CCAM/interstitial emphysema.

In 6 cases, the X-ray-based diagnosis was confirmed in CAT scan examination. In one case, CAT scan examination did not give an unequivocal response (lung sequestration or diaphragmatic hernia - it was necessary to examine the transit constipation). In 3 cases, CAT scanning showed the causes of changes visible in X-ray and verified the diagnosis (emphysema ventricle in X-ray - CCAM in CAT scanning; atelectasis of right lower lobe - caused by subphrenic hematoma; verification of enlarged cone of the heart asymmetry of the thoracic cage and disorder of diaphragm relaxation).

In one case, it revealed a pathology completely invisible in the X-ray (identical pathology in the second lung, invisible in classic $X$-ray examination - areas of interstitial emphysema).

Five neonates, after CAT scanning, underwent surgery. In 6 cases, after CAT scanning, following further treatment, there was improvement in the patient's state, in 3 neonates the clinical state levelled off, and in 1 case the result of the examination did not influence the course of the disease (relaxation of the right diaphragm dome). In the examined group, 1 neonate died, 4 were transferred to another ward for further treatment, and 5 in a good general state were discharged from hospital.

Table I.

\begin{tabular}{|c|c|c|c|c|c|}
\hline No. & Patient & Sex & Suspicion/clinical diagnosis & $\mathrm{X}$-ray diagnosis & CAT scanning diagnosis \\
\hline 1 & J.M. & $\mathrm{F}$ & Diaphragm flaccidity/hernia & Diaphragm flaccidity/hernia & Flaccidity of the diaphragm \\
\hline 2 & K.P. & M & $\begin{array}{l}\text { Post-RDS condition I/II, } \\
\text { emphysema ventricle/CCAM }\end{array}$ & Emphysema ventricle & CCAM \\
\hline 3 & K.W. & $\mathrm{F}$ & Suspicion of heart defect & Enlarged cone of the heart & $\begin{array}{c}\text { Asymmetry of the thoracic cage } \\
\text { Diaphragm relaxation }\end{array}$ \\
\hline 4 & K.K. & M & Polycystic disease/right lobe hernia & Polycystic disease of the right lobe & $\begin{array}{c}\text { Diaphragm hernia/lung sequ- } \\
\text { estration }\end{array}$ \\
\hline 5 & K.K. & M & Emphysema/lung distention & Emphysema/CCAM & CCAM \\
\hline 6 & M. 's' A. & M & CCAM & Interstitial emphysema & Persistent emphysema \\
\hline 7 & T.A. & M & Hematoma/subphrenic abscess & Atelectasis of the right lower lobe & $\begin{array}{c}\text { Post-operative subphrenic } \\
\text { hematoma, visible traits of } \\
\text { abscess }\end{array}$ \\
\hline 8 & N.J. & M & CCAM suspicion & Left emphysema/possible CCAM & CCAM/interstitial emphysema \\
\hline 9 & S.K. & M & $\begin{array}{l}\text { Non-characteristic auscultatory } \\
\text { changes }\end{array}$ & Persisting cystic shadow & $\begin{array}{l}\text { Consolidation area -inflamma- } \\
\text { tory and atelectatic changes }\end{array}$ \\
\hline 10 & S. 's' K. & M & $\begin{array}{c}\text { Condition after congenital pneumonia, } \\
\text { ARDS }\end{array}$ & $\begin{array}{l}\text { Post-RDS condition, areas of inter- } \\
\text { stitial emphysema present, ARDS }\end{array}$ & $\begin{array}{l}\text { Areas of interstitial emphyse- } \\
\text { ma/possible proteinosis }\end{array}$ \\
\hline
\end{tabular}




\section{Discussion}

Radiological examinations constitute a basis for the diagnostics of thoracic cage organs in neonates. A classic $\mathrm{X}$-ray photograph is one of the first examinations carried out in intensive care units. There are pathologies which are invisible in classic radiograms of the thoracic cage or the examinations do not reflect sufficiently precisely the anatomic relations of the suspected diseases.

Then, CAT scanning seems very useful; it is decisive in many cases [3]. It should be underlined that in spite of great specificity, it is a burden to the neonate. A high dose of radiation and the necessity to apply sedation should be a reason for clearly defined indications for this examination. The medical team, consisting of a radiologist, anaesthesiologist and paediatrician, takes a decision on the necessity of performing a CAT scan, which should be done only in case of obtaining benefits exceeding the examination-related risk. There should be premises indicating a positive influence of examination results on the treatment progress, e.g. a precise diagnosis - better adjusted treatment, presurgery evaluation of the situation, or a lack of sufficient information on co-existing diseases in the neonate.

The examination of the thoracic cage in neonates by means of CAT scanning is, in Polish conditions, carried out as a supplementary examination, answering the questions formed on the basis of classic X-ray photographs. However, it is extremely sensitive in detecting changes within the lung parenchyma $[4,5]$, and in detecting congenital defects [6] as well.

The group we examined is not large, but it is comparable to the groups examined by others $[4,7,8]$. Due to the rare indications for performing CAT scanning in neonates, many authors enlarge their groups with older children $[6,9]$.

In the above-discussed group of patients, most of them were boys (eight out of ten examined), as in the works of other centres [6].

\section{Conclusions}

On the basis of the centre's experience, we may draw the conclusion that the basic indication for performing CAT scan examination in neonates is the suspicion of anatomical irregularity in the form of:

1) congenital cystic adenomatoid malformation (CCAM),

2) increase of the mediastinum shadow of unknown origin,

3) flaccidity of the diaphragm,

4) precise evaluation of bone malformations of the thoracic cage,

5) interstitial emphysema,

6) diagnostics of diaphragmatic hernia,

7) evaluation of post-operative changes and surgery results in patients treated surgically.

\section{References}

1. Agrous GA, Courtney SE, Stocker JT, Markowitz RI. Lung disease In premature neonates: radiologic-pathologic correlation. Radiographics 2005; 25 : 1047-1073.

2. Hermansen CL, Lorah KN. Respiratory distress in the newborn. Am Fam Physician 2007; 76: 987-994.

3. Bhandari A, Bhandari V. Pitfalls, Problems, and Progress in Bronchopulmonary Dysplasia. Pediatrics 2009; 123: 1562.

4. O'Shea TM, Klebanoff MA, Signore C. Delivery after previous cesarean: long-term outcomes in the child. Semin Perinatol 2010; 34: 281-292.

5. Kocaoğlu M, Frush DP, Uğurel MS, Somuncu I. Bronchopulmonary foregut malformations presenting as mass lesions in children: spectrum of imaging findings. Diagn Interv Radiol 2010; 16: 153-161.

6. Schneebaum N, Blau H, Soferman R, Mussaffi H, Ben-Sira L, Schwarz M, Sivan Y. Use and Yield of Thoracic cage Computed Tomography in the Diagnostic Evaluation of Pediatric Lung Disease. Pediatrics 2009;124: 472; originally published online July 20, 2009, DOI: 10.1542/peds.2008-2694.

7. Walker SP, Chow YY, Ugoni AM, Holberton JR, Smith CL, Permezel MJ. Amniotic fluid lamellar body concentration as a marker of fetal lung maturity at term elective caesarean delivery. Aust N Z J Obstet Gynaecol 2010; 50 : 358-362.

8. Shimono R, Ibara S, Maruyama Y, Maruyama H, Tokuhisa T, Noguchi H, Takamatsu H. Radiographic findings of diaphragmatic hernia and hypoplastic lung. J Perinatol 2010; 30: 140-143.

9. Sly PD, Brennan S, Gangell C, de Klerk N, Murray C, Mott L, Stick SM, Robinson PJ, Robertson CF, Ranganathan SC. Lung disease at diagnosis in infants with cystic fibrosis detected by newborn screening. Am J Respir Crit Care Med 2009; 180: 146-152. 